\title{
Mono- and bimetallic lanthanide(III) phenolic cryptates obtained by template reaction: solid state structure, photophysical properties and relaxivity $\dagger$
}

\author{
Carlos Platas, ${ }^{a, c}$ Fernando Avecilla, ${ }^{a}$ Andrés de Blas, ${ }^{a}$ Teresa Rodríguez-Blas, ${ }^{* a}$ \\ Carlos F. G. C. Geraldes, ${ }^{b}$ Éva Tóth, $^{c}$ André E. Merbach ${ }^{c}$ and Jean-Claude G. Bünzli *c \\ ${ }^{a}$ Departamento de Química Fundamental e Industrial, Universidade da Coruña, \\ Campus de A Zapateiras/n 15071 A Coruña, Spain.E-mail: mayter@udc.es \\ ${ }^{b}$ Departamento de Bioquímica, Faculdade de Ciências e Tecnologia, e Centro de Neurociências, \\ Universidade de Coimbra, Apartado 3126, 3000 Coimbra, Portugal \\ ${ }^{c}$ Institute of Inorganic and Analytical Chemistry, University of Lausanne, CH-1015 Lausanne, \\ Switzerland.E-mail: jean-claude.bunzli@icma.unil.ch
}

Received 17th August 1999, Accepted 2nd December 1999

\begin{abstract}
We report here a structural and photophysical study of lanthanide monometallic complexes with the macrobicyclic axial phenolic cryptand $\mathrm{N}\left[\left(\mathrm{CH}_{2}\right)_{2} \mathrm{~N}=\mathrm{CH}-\mathrm{R}-\mathrm{CH}=\mathrm{N}\left(\mathrm{CH}_{2}\right)_{2}\right]_{3} \mathrm{~N}\left(\mathrm{R}=m-\mathrm{C}_{6} \mathrm{H}_{2} \mathrm{OH}-2-\mathrm{Me}-5\right) \mathrm{L}$ as well as of bimetallic complexes with its de-protonated form $(\mathrm{L}-3 \mathrm{H})^{3-}$. The X-ray crystal structure of $\left[\mathrm{DyL}\left(\mathrm{NO}_{3}\right)\right]\left(\mathrm{NO}_{3}\right)_{2} \cdot 2 \mathrm{CH}_{3} \mathrm{CN}$. $0.5 \mathrm{H}_{2} \mathrm{O}$ shows the metal ion being asymmetrically positioned into the macrobicyclic cavity and bonded to seven donor atoms of $\mathrm{L}$ and two oxygen atoms of a bidentate nitrate ion. The $\mathrm{X}$-ray crystal structure of the bimetallic cryptate, $\left[\mathrm{Dy}_{2}(\mathrm{~L}-3 \mathrm{H})\left(\mathrm{NO}_{3}\right)_{2}\right]\left(\mathrm{NO}_{3}\right) \cdot 3 \mathrm{H}_{2} \mathrm{O} \cdot \mathrm{MeOH}$, confirms that both Dy(III) ions are held into the cavity of the cryptand at a very short distance from each other, 3.4840(4) Å. High resolution laser-excited emission spectra of the crystalline monometallic Eu(III) cryptate point to the presence of a single site with low symmetry for the metal, while lifetime measurements in $\mathrm{H}_{2} \mathrm{O}$ and $\mathrm{D}_{2} \mathrm{O}$ solutions allowed us to estimate the number of bound water molecules, $q=1$. Both mono- and binuclear $\mathrm{Yb}(\mathrm{III})$ cryptates display strong emission upon excitation through the ligand electronic levels, the spectrum of the binuclear complex being consistent with the presence of two $\mathrm{Yb}$ (III) ions in different co-ordination environments. Proton NMRD profiles for the mononuclear Gd(III) complex have been measured in the temperature range $5-37^{\circ} \mathrm{C}$ and show that the relaxivity is mainly limited by fast rotation; this compound is stable towards acid-catalysed decomposition in aqueous solution only at $\mathrm{pH}>5.5$.
\end{abstract}

\section{Introduction}

Novel applications of trivalent lanthanide complexes as contrast agents for magnetic resonance imaging, ${ }^{1}$ catalysts for specific cleavage of $\mathrm{RNA}^{2}$ and stains for fluorescence imaging ${ }^{3}$ or cancer radiotherapy ${ }^{4}$ have prompted considerable interest in lanthanide co-ordination chemistry. ${ }^{5}$ Among the receptors used to encapsulate the $\mathrm{Ln}$ (III) ions, macrocyclic platforms play an essential role, ${ }^{6}$ especially for protecting the metal ion from external interactions and for generating a good antenna effect. Indeed, some lanthanide ions possess strongly emissive and long-lived excited states, such as Eu(III) and Tb(III), but do not exhibit intense absorption bands. ${ }^{7}$ Therefore, considerable effort has been devoted to the design of lanthanide complexes where light is absorbed by the ligands and the corresponding electronic energy is then transferred onto the emitting metal ion. Analogous sensitisation of $\mathrm{Nd}(\mathrm{III})$ and $\mathrm{Yb}(\mathrm{III})$, which emit in the near-infrared, remains relatively unexplored. The spectral luminescence of $\mathrm{Ln}$ (III) complexes ( $\mathrm{Ln}=\mathrm{Nd}, \mathrm{Eu}, \mathrm{Tb}$ and $\mathrm{Yb}$ ) has been studied with phenolic-type calix[4]arenes. ${ }^{8}$ The emission of $\mathrm{Yb}(\mathrm{III})$ has been studied in some complexes with different types of ligands such as diketonates, ${ }^{9}$ porphyrins, ${ }^{10}$ macrocyclic hydrazones ${ }^{11}$ and tetraazacyclododecane (12ane $\mathrm{N}_{4}$ ) based ligands. ${ }^{12}$ Horrocks and co-workers have recently described the sensitised emission of $\mathrm{Yb}$ (III) complexed in a protein by means of tryptophan moieties ${ }^{13}$ and luminescence spectra of $\mathrm{Nd}(\mathrm{III})$ complexes have also been reported recently. ${ }^{14}$

$\uparrow$ Electronic supplementary information (ESI) available: table with selected bond angles for cryptates $\mathbf{4}$ and 7 and emission spectra for the Eu $1: 1$ cryptate. See http://www.rsc.org/suppdata/dt/a9/a906675f/
In previous papers, we have demonstrated the ability of trivalent lanthanide ions to promote the formation of Schiff base axial macrobicyclic ligands. ${ }^{15}$ Monometallic cryptates with the axial cryptand $\mathrm{L}, \mathrm{N}\left[\left(\mathrm{CH}_{2}\right)_{2} \mathrm{~N}=\mathrm{CH}-\mathrm{R}-\mathrm{CH}=\mathrm{N}\left(\mathrm{CH}_{2}\right)_{2}\right]_{3} \mathrm{~N} \quad(\mathrm{R}=$ $m-\mathrm{C}_{6} \mathrm{H}_{2} \mathrm{OH}-2-\mathrm{Me}-5$ ) (Scheme 1), and with its tert-butylated analogue have been obtained for $\mathrm{Ln}=\mathrm{Sc}, \mathrm{Y}, \mathrm{Gd}, \mathrm{Eu}, \mathrm{Tb}$ and Dy by transmetallation of the sodium derivatives. ${ }^{16}$ In a subsequent work, we have shown that the 1:1 cryptates [LnL$\left.\left(\mathrm{NO}_{3}\right)\right]\left(\mathrm{NO}_{3}\right)_{2} \cdot x \mathrm{H}_{2} \mathrm{O}(\mathrm{Ln}=\mathrm{La}-\mathrm{Lu})$ could also be obtained by direct template reaction and we have reported their structure in both the solid state and in aqueous solution. ${ }^{17}$ The corresponding anionic cryptand $(\mathrm{L}-3 \mathrm{H})^{3-}$ is able to accommodate two $\mathrm{Ln}$ (III) ions into the macrobicyclic cavity and yield complexes with formula $\left[\mathrm{Ln}_{2}(\mathrm{~L}-3 \mathrm{H})\left(\mathrm{NO}_{3}\right)_{2}\right]\left(\mathrm{NO}_{3}\right) \cdot x \mathrm{H}_{2} \mathrm{O} \cdot y \mathrm{EtOH}$, which are the first bimetallic lanthanide iminophenolate cryptates reported to date. ${ }^{18}$ While the photophysical properties of Ln(III) complexes with Schiff base monomacrocyclic ligands have been widely investigated, ${ }^{19}$ no similar study with Schiff base macrobicyclic ligands is available. In this paper, we report the photophysical properties of both the mono- and bimetallic lanthanide(III) cryptates. To substantiate the discussion, the $\mathrm{X}$-ray crystal structures of the mono- and bi-dysprosium cryptates are also reported. Finally, since the cryptates contain water molecules in the inner co-ordination sphere, we have assessed the potential of the Gd compound as a contrast agent by measuring its relaxivity versus several parameters.

\section{Results and discussion}

The monometallic $\mathrm{Ln}(\mathrm{III})$ cryptates of formula $\left[\mathrm{LnL}\left(\mathrm{NO}_{3}\right)\right]-$ $\left(\mathrm{NO}_{3}\right)_{2} \cdot x \mathrm{H}_{2} \mathrm{O}$ were prepared as previously described, ${ }^{17}$ while the 


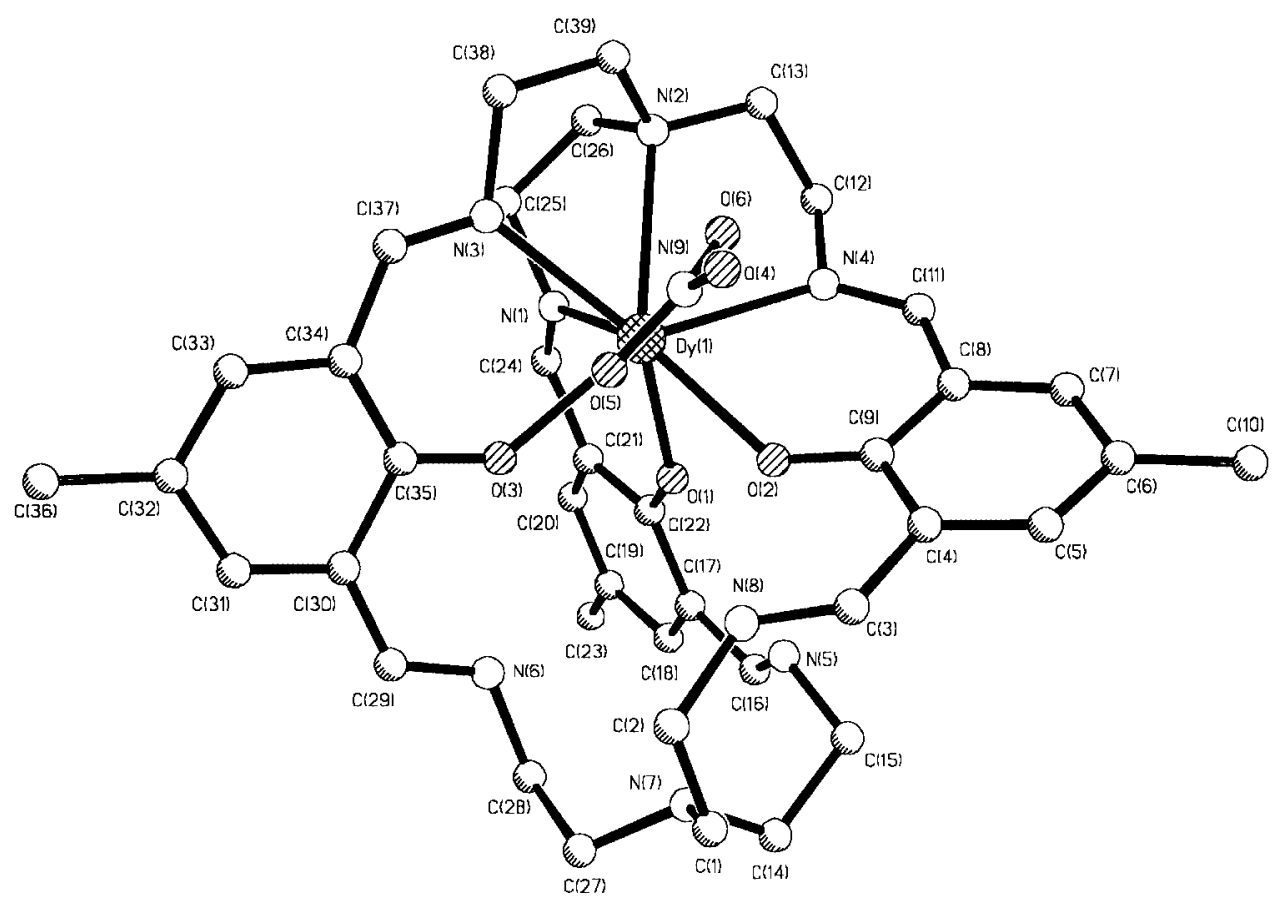

Fig. 1 Molecular structure of $\left[\mathrm{DyL}\left(\mathrm{NO}_{3}\right)\right]^{2+}$; hydrogen atoms are omitted for simplicity.

corresponding bimetallic cryptates of formula $\left[\mathrm{Ln}_{2}(\mathrm{~L}-3 \mathrm{H})\right.$ $\left.\left(\mathrm{NO}_{3}\right)_{2}\right]\left(\mathrm{NO}_{3}\right) \cdot x \mathrm{H}_{2} \mathrm{O} \cdot y$ EtOH were synthesised by a template reaction between triethylammonium 2,6-diformyl-4-methylphenolate and tris(2-aminoethyl)amine in the presence of hydrated lanthanide nitrates (see Scheme 1 for compound numbering).

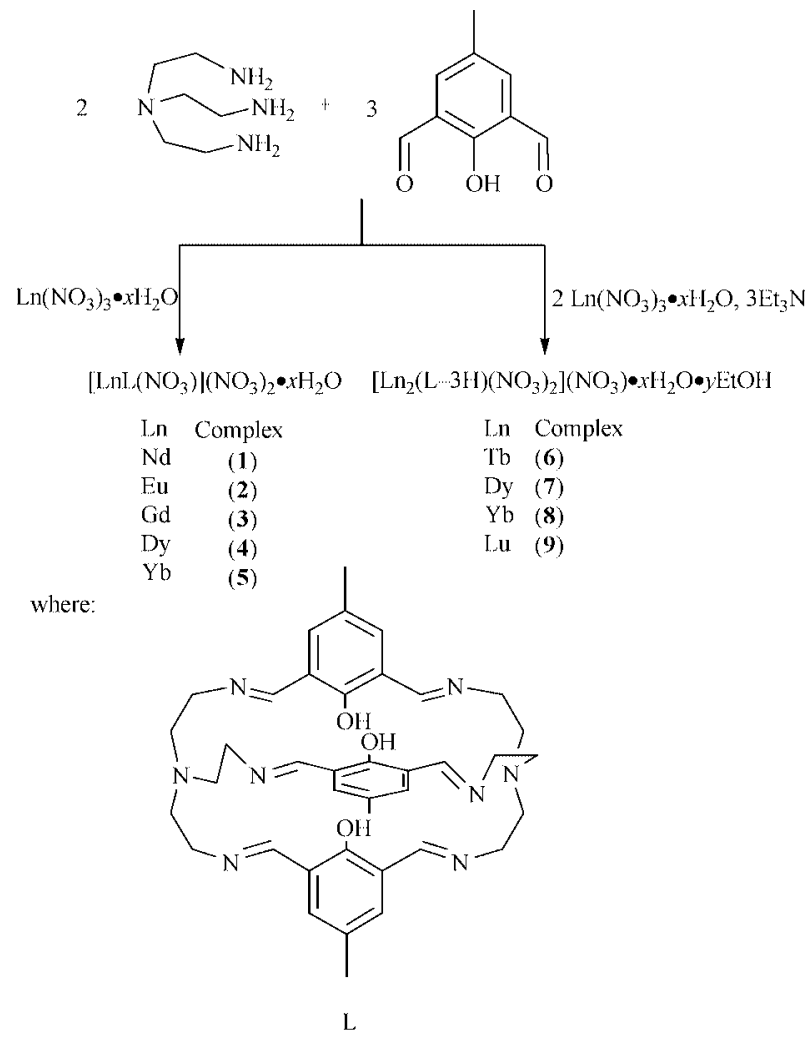

Scheme 1

Structural characterisation of the Dy mono- and bimetallic cryptates

Crystals of $\left[\mathrm{DyL}\left(\mathrm{NO}_{3}\right)\right]\left(\mathrm{NO}_{3}\right)_{2} \cdot 2 \mathrm{CH}_{3} \mathrm{CN} \cdot 0.5 \mathrm{H}_{2} \mathrm{O}(4)$ consist of $\left[\mathrm{DyL}\left(\mathrm{NO}_{3}\right)\right]^{2+}$ cations (Fig. 1), two well separated nitrate anions and interstitial acetonitrile and water molecules. The dication
Table 1 Selected bond lengths ( $\AA$ ) for cryptates $\mathbf{4}$ and 7

\begin{tabular}{lllll}
\hline & $\mathbf{4}$ & $\mathbf{7}$ & & $\mathbf{7}$ \\
\hline $\mathrm{Dy}(1)-\mathrm{O}(1)$ & $2.297(6)$ & $2.380(5)$ & $\mathrm{Dy}(2)-\mathrm{O}(1)$ & $2.322(4)$ \\
$\mathrm{Dy}(1)-\mathrm{O}(2)$ & $2.344(6)$ & $2.308(4)$ & $\mathrm{Dy}(2)-\mathrm{O}(2)$ & $2.392(5)$ \\
$\mathrm{Dy}(1)-\mathrm{O}(3)$ & $2.285(7)$ & $2.389(5)$ & $\mathrm{Dy}(2)-\mathrm{O}(3)$ & $2.406(5)$ \\
$\operatorname{Dy}(1)-\mathrm{O}(5)$ & $2.620(7)$ & $2.814(6)$ & Dy(2)-O(8) & $2.405(7)$ \\
Dy(1)-O(6) & $2.417(7)$ & $2.463(5)$ & Dy(2)-O(9B) & $2.767(13)$ \\
Dy(1)-N(1) & $2.511(7)$ & $2.494(6)$ & Dy(2)-N(5) & $2.411(6)$ \\
Dy(1)-N(2) & $2.695(7)$ & $2.666(5)$ & Dy(2)-N(6) & $2.458(7)$ \\
Dy(1)-N(3) & $2.488(8)$ & $2.471(6)$ & Dy(2)-N(7) & $2.624(6)$ \\
Dy(1)-N(4) & $2.517(8)$ & $2.426(6)$ & Dy(2)-N(8) & $2.472(6)$ \\
\hline
\end{tabular}

contains a $\mathrm{DyN}_{4} \mathrm{O}_{5}$ core with the metal ion asymmetrically placed at one end of the cavity of the macrobicyclic receptor and bound to seven of the eleven heteroatoms of the ligand [three imino-nitrogen atoms, $\mathrm{N}(1), \mathrm{N}(3), \mathrm{N}(4)$, one of the bridgehead nitrogen atoms, $\mathrm{N}(2)$, and the three phenolic oxygen atoms, $\mathrm{O}(1), \mathrm{O}(2), \mathrm{O}(3)]$ as well as to a bidentate nitrato group. Selected distances and angles are listed in Table 1 and Table S1 (supporting information), respectively. The Dy-X distances are in the range 2.49-2.52 $\AA$ for the azomethine nitrogen atoms, and 2.29-2.34 $\AA$ for the phenolic oxygen atoms. Two of the latter, $\mathrm{Dy}-\mathrm{O}(1)$ and $\mathrm{Dy}-\mathrm{O}(3)$, agree with the Dy-O distances observed for phenolate compounds, ${ }^{20}$ which allows one to consider that a proton transfer from the co-ordinated phenoxy oxygen atoms to the imine nitrogen atoms has occurred, as previously observed for similar cryptates. ${ }^{16,21}$ The mean distance between Dy(III) and the bridgehead nitrogen atoms is $c a .0 .2 \AA$ longer than the mean Dy-N(azomethine) distance, pointing to a weak interaction between the amine nitrogen and the metal ion. The Dy(III) ion lies $0.93 \AA$ below the pseudo-plane formed by the three azomethine nitrogen atoms, N(1), N(3), N(4), and the oxygen atom, $\mathrm{O}(6)$, of the nitrate group (deviation from planarity, $0.11 \AA$ ) and $1.52 \AA$ above the plane defined by the three phenolic oxygen atoms. The co-ordination polyhedron can be best described as a slightly distorted monocapped dodecahedron with the $\mathrm{O}(5)$ of the co-ordinated nitrate group capping the dodecahedron. The macrobicycle $\mathrm{L}$ is twisted around the axis that passes through both bridgehead nitrogen atoms, forming a triple helical arrangement, and it adopts an sss endo-endo conformation, with the nitrogen atoms of the imine bonds being on the same side of the aromatic ring in the 


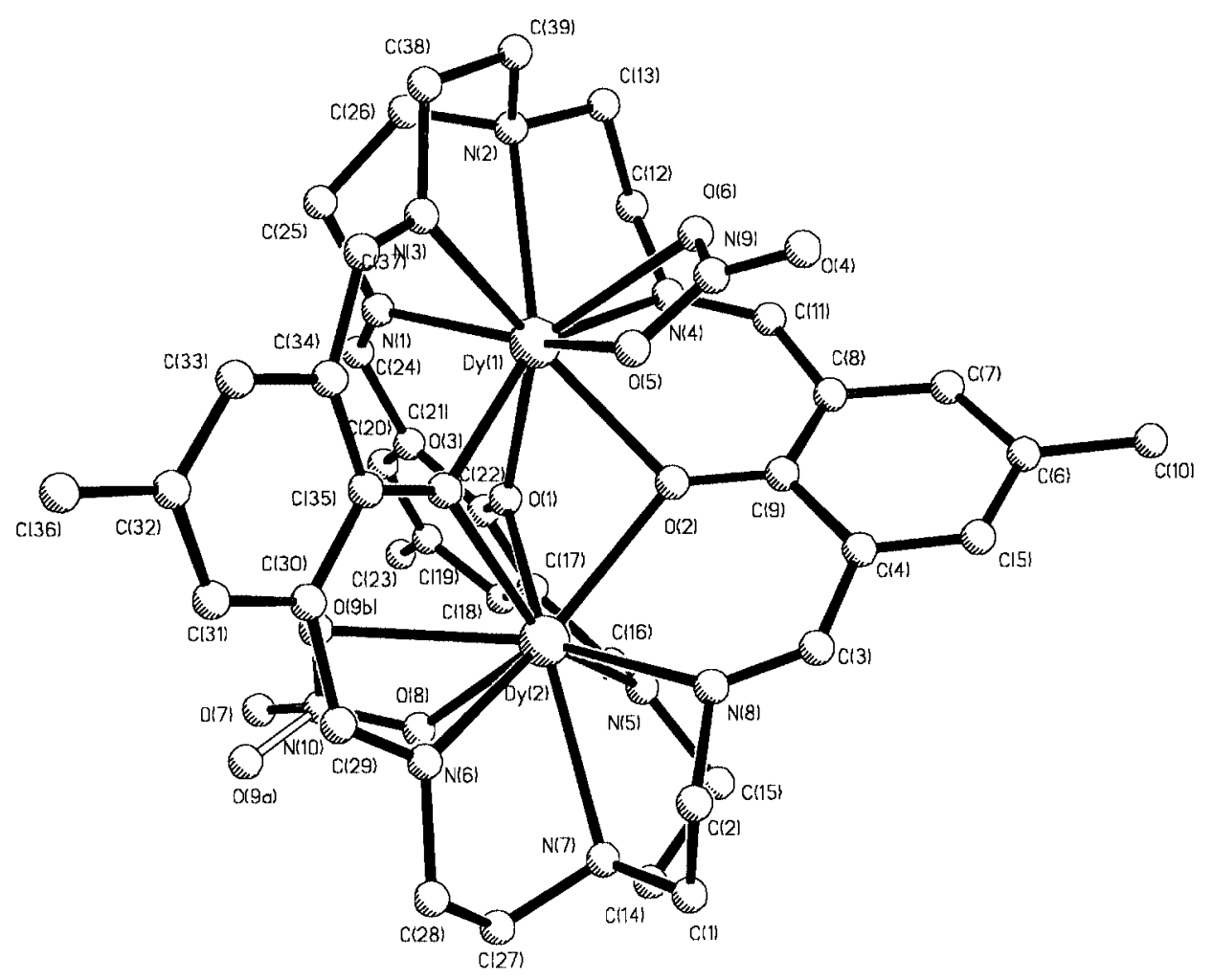

Fig. 2 Molecular structure of $\left[\mathrm{Dy}_{2}(\mathrm{~L}-3 \mathrm{H})\left(\mathrm{NO}_{3}\right)_{2}\right]^{+}$; hydrogen atoms are omitted for simplicity.

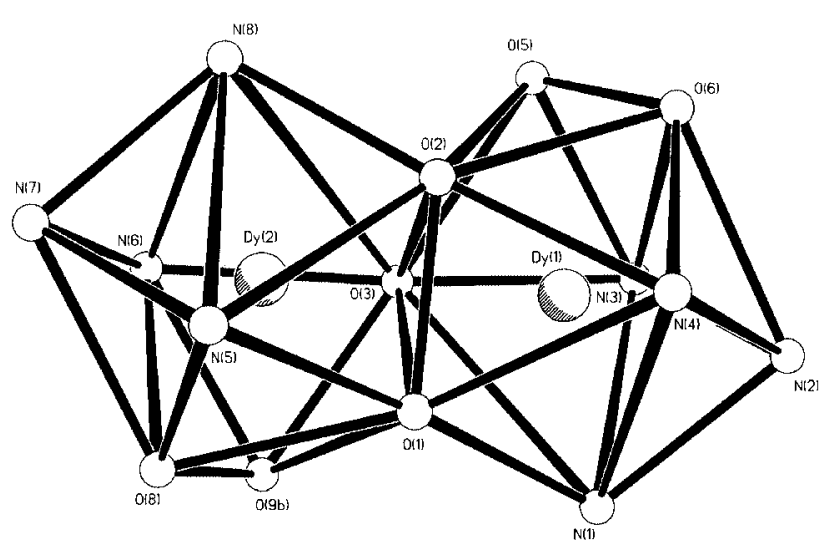

Fig. 3 View of the co-ordination geometry in $\left[\mathrm{Dy}_{2}(\mathrm{~L}-3 \mathrm{H})\left(\mathrm{NO}_{3}\right)_{2}\right]^{+}$.

three chains and the bridgehead nitrogen lone pairs directed inward towards the central cavity. The angles between the planes defined by the phenolic rings have values of $65.2,87.7$ and $85.7^{\circ}$; the distances between the phenoxy oxygen atoms are 2.67, 2.78 and $3.38 \AA$, while the bridgehead nitrogen atoms are separated by $8.34 \AA$, a distance shorter than those found in $\mathrm{Ce}, \mathrm{Nd}$ and $\mathrm{Eu}$ mononuclear cryptates. ${ }^{17}$

The crystals of $\left[\mathrm{Dy}_{2}(\mathrm{~L}-3 \mathrm{H})\left(\mathrm{NO}_{3}\right)_{2}\right]\left(\mathrm{NO}_{3}\right) \cdot 3 \mathrm{H}_{2} \mathrm{O} \cdot \mathrm{MeOH}(7)$ are composed of $\left[\mathrm{Dy}_{2}(\mathrm{~L}-3 \mathrm{H})\left(\mathrm{NO}_{3}\right)_{2}\right]^{+}$cations (Fig. 2), an independent nitrate anion and highly disordered molecules of methanol and water. Bond lengths and angles are summarised in Table 1 and Table S1 (supporting information), respectively. Both Dy(III) ions are positioned in the cavity of the anionic Schiff base macrobicyclic receptor $(\mathrm{L}-3 \mathrm{H})^{3-}$ and have crystallographically identical co-ordination environments; each is nine co-ordinated, being bound to one bridgehead nitrogen atom, three azomethine nitrogen atoms, two oxygen atoms of a bidentate nitrate group and to the three $\mu$-phenolate oxygen atoms. The Dy-O(phenolate) distances are in the range 2.31$2.41 \AA$ and the Dy-N(imine) distances have values from 2.41 to $2.49 \AA$; the former is slightly longer than those found in the mononuclear cryptate $\mathbf{4}$ and the latter is shorter than those of 4 .
The Dy(1) atom lies $0.87 \AA$ below the plane formed by $\mathrm{N}(1)$, $\mathrm{N}(3), \mathrm{N}(4)$ and $\mathrm{O}(6)$ (deviation from planarity $0.06 \AA$ ) and $1.75 \AA$ above the plane defined by the three $\mu$-phenolate oxygen atoms, $\mathrm{O}(1), \mathrm{O}(2)$ and $\mathrm{O}(3)$. The $\mathrm{Dy}(2)$ ion lies $1.73 \AA$ away from the latter plane and $0.90 \AA$ away from the one delineated by $\mathrm{N}(5), \mathrm{N}(6), \mathrm{N}(8)$ and $\mathrm{O}(8)$ (deviation from planarity $0.07 \AA$ ). These data reveal that both metal ions are farther from the plane defined by the $\mu$-phenolate oxygen atoms than in the case of the monometallic cryptate 4 , probably in view of the large electrostatic repulsion that would otherwise occur between two tripositive ions placed so close together. Even so, the presence of the phenolate groups allows the ions to be situated in close proximity, Dy(1)-Dy(2) 3.4840(4) Å. The co-ordination polyhedron around each metal ion can be best described as a monocapped distorted dodecahedron, as shown in Fig. 3. In cryptate 7 the anionic macrobicyclic receptor $(\mathrm{L}-3 \mathrm{H})^{3-}$ also adopts the sss endo-endo conformation, which in this case is necessary for the complexation of both metal ions into its cavity, and again is twisted around the $\mathrm{N}(2)-\mathrm{N}(7)$ axis. Both metal ions slightly deviate from this axis with a N(2)-Dy-N(7) angle equal to $166^{\circ}$. The angles between the phenolate ring planes amount to $68.7,98.8$ and $103.7^{\circ}$, respectively. The macrobicyclic cavity is clearly more elliptical in this bimetallic cryptate than it is in the mononuclear complex, as inferred from the distance between the two bridgehead nitrogen atoms $[\mathrm{N}(2)-\mathrm{N}(7)=8.687 \AA], c a$. $0.35 \AA$ longer than that observed in $\mathbf{4}$, and from the distances between each pair of phenolate oxygen atoms $(2.17,2.17$ and $2.15 \AA$ ), which are much shorter than in $\mathbf{4}$.

\section{Photophysical properties of the $\left[\mathrm{LnL}\left(\mathrm{NO}_{3}\right)\right]\left(\mathrm{NO}_{3}\right)_{2} \cdot x \mathrm{H}_{2} \mathrm{O}$ cryptates}

Relevant photophysical data are presented in Table 2. Electronic spectra of the monometallic cryptates display three regions of absorption; a band centred around $24500 \mathrm{~cm}^{-1}$ typical of polyaza macrocycles and which has been assigned to the $\mathrm{C}=\mathrm{N}$ chromophores, ${ }^{22}$ a double band at $c a .36500$ and $40000 \mathrm{~cm}^{-1}$ arising from transitions located on the substituted phenol moieties and an intense absorption around $45800 \mathrm{~cm}^{-1}$. Upon excitation through the ligand levels, one ligand-centred 
Table 2 Ligand-centred absorption and emission properties. Energies are given in $\mathrm{cm}^{-1}$

\begin{tabular}{|c|c|c|c|c|}
\hline Compound & $E^{a}$ & $E^{b}$ & $E\left({ }^{1} \pi \pi^{*}\right)$ & $E\left({ }^{3} \pi \pi^{*}\right)^{f} \tau\left({ }^{3} \pi \pi^{*}\right) / \mathrm{ms}$ \\
\hline \multirow{4}{*}[\mathrm{EuL}(\mathrm{NO}_{3})]{$^{2+}(2)$} & $24630(4.37)$ & 22170 & $18710^{c}$ & $g$ \\
\hline & $36360(4.62)$ & 36500 & & \\
\hline & 40160 (4.67) & 42920 & & \\
\hline & 45870 (4.98) & & & \\
\hline \multirow{4}{*}[\mathrm{GdL}(\mathrm{NO}_{3})]{$^{2+}(\mathbf{3})$} & $24480(4.30)$ & & $19710^{d}$ & 16390 \\
\hline & $36890(4.58)$ & & & 14990 \\
\hline & 39880 (4.69) & & & $0.7 \pm 0.1$ \\
\hline & 45780 (4.97) & & & \\
\hline \multirow{4}{*}[\operatorname{DyL}(\mathrm{NO}_{3})]{$^{2+}(\mathbf{4})$} & $24520(4.33)$ & 22170 & $19560^{d}$ & $g$ \\
\hline & 36260 (4.58) & 36360 & & \\
\hline & 40080 (4.66) & 44640 & & \\
\hline & 45700 (4.95) & & & \\
\hline \multirow{4}{*}[\mathrm{YbL}(\mathrm{NO}_{3})]{$^{2+}(\mathbf{5})$} & $24550(4.35)$ & 22620 & $19560^{d}$ & $g$ \\
\hline & $36210(4.60)$ & 36900 & & \\
\hline & 39960 (4.67) & & & \\
\hline & 45940 (4.97) & & & \\
\hline \multicolumn{2}{|l|}{$\left[\mathrm{Yb}_{2}(\mathrm{~L}-3 \mathrm{H})\left(\mathrm{NO}_{3}\right)_{2}\right]^{+}(\mathbf{8})$} & 23640 & $17590^{e}$ & $g$ \\
\hline \multirow[t]{2}{*}[\mathrm{Lu}_{2}(\mathrm{L}-3\mathrm{H})(\mathrm{NO}_{3})_{2}]{$^{+}(\mathbf{9})$} & $26810(4.50)$ & $\begin{array}{l}36900 \\
23260\end{array}$ & $18250^{e}$ & 16600 \\
\hline & $38610(5.08)$ & 36770 & & $24 \pm 1$ \\
\hline
\end{tabular}

${ }^{a}$ Electronic spectral data in acetonitrile at $295 \mathrm{~K}$; energies are given for the maximum of the band envelope in $\mathrm{cm}^{-1} ; \log \varepsilon$ given within parentheses. ${ }^{b}$ Reflectance spectra recorded at $295 \mathrm{~K}$. ${ }^{c}$ Luminescence spectrum of aqueous solution at $295 \mathrm{~K}$. ${ }^{d}$ Luminescence spectra of acetonitrile solutions at $295 \mathrm{~K}$. ${ }^{e}$ Luminescence spectra of DMSO solutions at $295 \mathrm{~K} .{ }^{f}$ Luminescence data and lifetimes at $10 \mathrm{~K}$ (solid state). ${ }^{g}$ Luminescence quenched by transfer to the Ln ion.

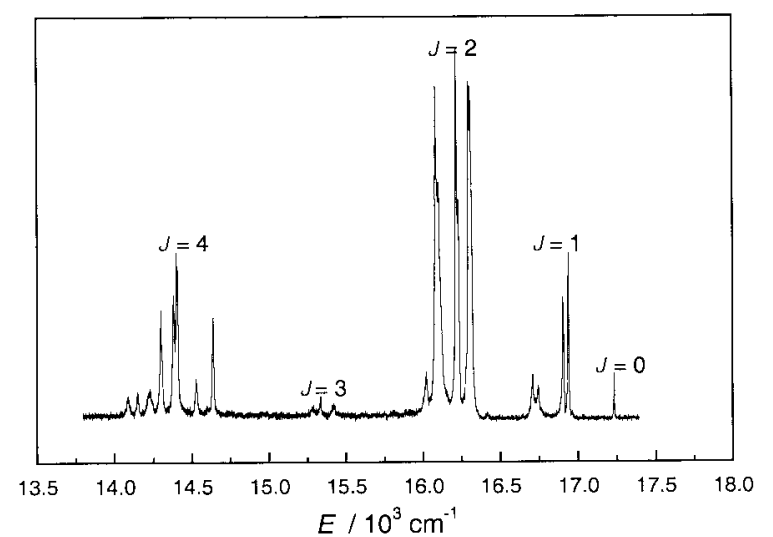

Fig. 4 Emission spectrum of the $\left[\mathrm{EuL}\left(\mathrm{NO}_{3}\right)\right]\left(\mathrm{NO}_{3}\right)_{2} \cdot 4 \mathrm{H}_{2} \mathrm{O}$ cryptate in the solid state at $10 \mathrm{~K}\left(v_{\mathrm{exc}}=22075 \mathrm{~cm}^{-1}\right)$.

emission band is observed, the intensity of which quickly diminishes when a short time delay is enforced and which can therefore be assigned as arising from a ${ }^{1} \pi \pi^{*}$ state. The absolute quantum yield of the ligand-centred luminescence is quite low and amounts to $Q^{\mathrm{F}}=0.2 \%$. Emission from the ligand triplet state could be identified in the case of the Gd cryptate, in the solid state at $10 \mathrm{~K}$; it occurs at low energy, in the range 15000 $17000 \mathrm{~cm}^{-1}$ and its lifetime is short, around $0.7 \mathrm{~ms}$. In the Eu, Dy and $\mathrm{Yb}$ complexes, this emission is completely quenched by an energy transfer process onto the metal ion.

Luminescence properties of the Eu cryptate. A high resolution study has been performed on a solid sample of the Eu cryptate $\mathbf{2}$ to gain information on the chemical environment of the metal ion. Upon excitation in the ligand ${ }^{1} \pi \pi^{*}$ state at $10 \mathrm{~K}$, the emission spectrum displays the characteristic $\mathrm{Eu}\left({ }^{5} \mathrm{D}_{0} \rightarrow{ }^{7} \mathrm{~F}_{J}\right)$ transitions (Fig. 4). The integrated and corrected relative intensities of the ${ }^{5} \mathrm{D}_{0} \rightarrow{ }^{7} \mathrm{~F}_{J}$ transitions are $0.05,1.00,5.77,0.17$ and 2.06 for $J=0,1,2,3$ and 4 , respectively. The ${ }^{5} \mathrm{D}_{0} \rightarrow{ }^{7} \mathrm{~F}_{0}$ transition, which is unique for a given chemical environment, occurs at 17232 $\mathrm{cm}^{-1}$ with a full width at half height (fwhh) of $4.65 \mathrm{~cm}^{-1}$, typical of a well defined co-ordination site. However, it also displays a shoulder at $17230 \mathrm{~cm}^{-1}$ and a very faint component at $17241 \mathrm{~cm}^{-1}$, and transitions to the ${ }^{7} \mathrm{~F}_{1}$ and ${ }^{7} \mathrm{~F}_{2}$ levels contain more than the expected $(2 J+1)$ components. The excitation
Table 3 Crystal field sub-levels of the $\mathrm{Eu}\left({ }^{7} \mathrm{~F}_{J}\right)$ manifold $(J=1-4$, $\left.\mathrm{cm}^{-1}\right)$ in $\left[\mathrm{EuL}\left(\mathrm{NO}_{3}\right)\right]\left(\mathrm{NO}_{3}\right)_{2} \cdot 4 \mathrm{H}_{2} \mathrm{O}$, as determined from excitation and emission spectra at $10 \mathrm{~K} ;{ }^{7} \mathrm{~F}_{0}$ is taken as the origin

\begin{tabular}{|c|c|c|c|c|c|c|c|}
\hline${ }^{7} F_{1}$ & $\begin{array}{l}295 \\
329 \\
524\end{array}$ & ${ }^{7} \mathrm{~F}_{2}{ }^{a}$ & $\begin{array}{r}925 \\
933 \\
1002 \\
1017 \\
1134 \\
1149\end{array}$ & ${ }^{7} \mathrm{~F}_{3}$ & $\begin{array}{l}1811 \\
1900 \\
1943 \\
1953\end{array}$ & ${ }^{7} \mathrm{~F}_{4}$ & $\begin{array}{l}2595 \\
2704 \\
2833 \\
2852 \\
2933 \\
3005 \\
3016 \\
3084 \\
3146\end{array}$ \\
\hline
\end{tabular}

spectrum in the ${ }^{5} \mathrm{D}_{0} \leftarrow{ }^{7} \mathrm{~F}_{0}$ region obtained by analysing the maximum of the ${ }^{5} \mathrm{D}_{0} \rightarrow{ }^{7} \mathrm{~F}_{2}$ transition at $10 \mathrm{~K}$ displays a single sharp peak at $17234 \mathrm{~cm}^{-1}$ (fwhh $=2.4 \mathrm{~cm}^{-1}$, Fig. S1, supporting information). Analysing on other components of the ${ }^{5} \mathrm{D}_{0} \rightarrow{ }^{7} \mathrm{~F}_{1}$ or ${ }^{5} \mathrm{D}_{0} \rightarrow{ }^{7} \mathrm{~F}_{2}$ transitions reveals additional maxima, but when the excitation spectrum is recorded by setting the analysing energy on the ${ }^{5} \mathrm{D}_{0} \rightarrow{ }^{7} \mathrm{~F}_{4}$ transition, the excitation spectrum becomes identical to that obtained by monitoring the maximum of the ${ }^{5} \mathrm{D}_{0} \rightarrow{ }^{7} \mathrm{~F}_{2}$ transition. Moreover, emission spectra obtained by selective excitation on the various components of the ${ }^{5} \mathrm{D}_{0} \leftarrow{ }^{7} \mathrm{~F}_{0}$ transition are quite similar, but for the splitting of some emission lines (Fig. S2, supporting information). We therefore conclude that vibronic transitions are responsible for this situation. ${ }^{23}$ Indeed, a correlation between the infrared and luminescence spectra in the energy range of the transitions to ${ }^{7} \mathrm{~F}_{1}$ and ${ }^{7} \mathrm{~F}_{2}$ (Fig. S3, supporting information) clearly shows that some of the emission peaks are of vibronic origin. Increasing the temperature results in a typical broadening of these lines. Other splitting observed for some ${ }^{7} \mathrm{~F}_{2}$ emission bands in two sharp components may arise from Fermi-type resonances ${ }^{24}$ between the ${ }^{7} \mathrm{~F}_{2}$ sub-levels and the phonon density of states, $c f$., for instance, the components at 1002 and 1017 $\mathrm{cm}^{-1}$ or 1134 and $1149 \mathrm{~cm}^{-1}$ could originate from an interaction with vibrations at 1015 and $1149 \mathrm{~cm}^{-1}$, respectively. The emission spectra of $\mathbf{2}$ are therefore consistent with the presence of one single site of low symmetry for the $\mathrm{Eu}(\mathrm{III})$ ion. Electronic sub-levels of the ${ }^{7} \mathrm{~F}_{J}(J=1-4)$ manifold are reported in Table 3. 
Table 4 Lifetime of the $\mathrm{Eu}\left({ }^{5} \mathrm{D}_{0}\right)$ level in $\left[\mathrm{EuL}\left(\mathrm{NO}_{3}\right)\right]\left(\mathrm{NO}_{3}\right)_{2} \cdot 4 \mathrm{H}_{2} \mathrm{O}$

\begin{tabular}{lclll}
\hline Sample & $T / \mathrm{K}$ & $v_{\mathrm{exc}} / \mathrm{cm}^{-1}$ & $v_{\mathrm{an}} / \mathrm{cm}^{-1}$ & $\tau_{\mathrm{f}} / \mathrm{ms}$ \\
\hline Solid & 10 & 22075 & 14401 & $635 \pm 11$ \\
& & 17232 & 14401 & $642 \pm 1$ \\
Solid & 77 & 22075 & 14401 & $607 \pm 3$ \\
& & 17232 & 14401 & $614 \pm 4$ \\
Solid & 295 & 21278 & 16303 & $a$ \\
& & 17244 & 16303 & $288 \pm 4$ \\
$10^{-3} \mathrm{M}$ in $\mathrm{H}_{2} \mathrm{O}$ & 295 & 20921 & 16332 & $470 \pm 50$ \\
$10^{-3} \mathrm{M}$ in $\mathrm{D}_{2} \mathrm{O}$ & 295 & 20921 & 16332 & $860 \pm 70$ \\
${ }^{a}$ Not determined. & & & & \\
\hline
\end{tabular}

At low temperature, the lifetimes of the $\mathrm{Eu}\left({ }^{5} \mathrm{D}_{0}\right)$ level (Table 4) are in the range 630-640 $\mu$ s and are consistent with the presence of three closely diffusing $\mathrm{O}-\mathrm{H}$ or $\mathrm{N}-\mathrm{H}$ oscillators ( $c f$. the discussion of the structure of the Dy cryptate) in the vicinity of the $\mathrm{Eu}(\mathrm{III})$ ion and of a very low-lying triplet state, the energy of which is comparable to that of the ${ }^{5} \mathrm{D}_{0}$ level. Upon increasing the temperature, the lifetime becomes considerably shorter, which is indicative of a temperaturedependent quenching mechanism, such as mixing with ligand vibrational modes or back transfer to the ${ }^{3} \pi \pi^{*}$ state of the ligand. The presence of a quenching by a ligand-to-metal charge transfer ${ }^{25}$ state cannot be ruled out either, but we were unable to evidence a LMCT transition in the absorption spectrum of 2.

A correlation between the energy of the ${ }^{5} \mathrm{D}_{0} \rightarrow{ }^{7} \mathrm{~F}_{0}$ transition and parameters describing the nephelauxetic effect, $\delta_{\mathrm{i}}$, produced by the co-ordinating atoms has been proposed:26 $v-v_{0}=$ $C_{\mathrm{CN}} \Sigma n_{\mathrm{i}} \delta_{\mathrm{i}}$, where $C_{\mathrm{CN}}=1$ for a co-ordination number of $9, n_{\mathrm{i}}$ is the number of atoms of type i, and $v_{0}=17374 \mathrm{~cm}^{-1}$ at $295 \mathrm{~K}$. Taking into account the reported values for $\delta_{\mathrm{OH}}(-11.6), \delta_{\mathrm{NO}}$ $(-13.3)$, and $\delta_{\mathrm{N}}$ (amine, -12.1$)$, we calculate a nephelauxetic parameter, $\delta_{\mathrm{C}=\mathrm{N}}=-19.5$, for the three imine functions of $\mathrm{L}$ from our experimental value $v=17242 \mathrm{~cm}^{-1}$ at $295 \mathrm{~K}$. We have already demonstrated that heterocyclic amines produce a larger effect than aliphatic amines, for instance $\delta_{\mathrm{N}}=-15.3$ in complexes with benzimidazole pyridines. ${ }^{27}$ In our case, the large nephelauxetic effect produced by the imine $\mathrm{N}$ atoms of ligand $\mathrm{L}$ is in agreement with the shorter mean $\mathrm{Eu}-\mathrm{N}$ (imine) bond distance found for the $\left[\mathrm{EuL}\left(\mathrm{NO}_{3}\right)\right]^{2+}$ cation, $2.57 \AA$, compared with the Eu-N(amine) of $2.71 \AA \AA^{17}$ Moreover, large contact contributions have been evidenced for imine protons in the ${ }^{1} \mathrm{H}-\mathrm{NMR}$ spectrum of the Eu cryptate. ${ }^{17}$

Under excitation through the ligand levels, $10^{-3} \mathrm{M}$ solutions of 2 in $\mathrm{H}_{2} \mathrm{O}$ and $\mathrm{D}_{2} \mathrm{O}(\mathrm{pH} / \mathrm{D}=6.5)$ display an emission spectrum composed of a broad band arising from the ${ }^{1} \pi \pi^{*}$ state as well as weak bands from the Eu(III) ion. Using Horrock's equation for the calculation of the number of co-ordinated water molecules, ${ }^{23} q=1.05\left(k_{\mathrm{H}_{2} \mathrm{O}}-k_{\mathrm{D}_{2} \mathrm{O}}\right)$, we find $q=1.01$, indicating that the nitrate ion most probably dissociates and is replaced by a water molecule in the inner co-ordination sphere of the metal ion.

Photophysical properties of the Nd and Yb cryptates. Since L possesses a low-energy triplet state, it appears that it would be suited for sensitisation of $\mathrm{Nd}($ III) and $\mathrm{Yb}$ (III) ions. For the $\mathrm{Nd}$ cryptate a weak structured emission band is observed in the solid state at $295 \mathrm{~K}$ under laser excitation of the ${ }^{4} \mathrm{G}_{5 / 2}$ level only, which we assign to the ${ }^{4} \mathrm{~F}_{3 / 2} \rightarrow{ }^{4} \mathrm{I}_{9 / 2}$ transition with components at $10900,11030,11440$ and $11530 \mathrm{~cm}^{-1}$. In $\mathrm{Nd}(\mathrm{III})$, the energy gap $\Delta E\left({ }^{4} \mathrm{~F}_{3 / 2}-{ }^{4} \mathrm{I}_{15 / 2}\right)=5400 \mathrm{~cm}^{-1}$ is quite small and is easily matched by $\mathrm{C}-\mathrm{H}, \mathrm{O}-\mathrm{H}$, or $\mathrm{N}-\mathrm{H}$ vibrations, leading to an effective quenching of the ${ }^{4} \mathrm{~F}_{3 / 2}$ excited state and henceforth a weak emission.

The luminescence spectrum of the $\mathrm{Yb}$ cryptate $\mathbf{5}$, recorded in the solid state at $10 \mathrm{~K}$ under excitation through the ligand levels, consists of an intense band at $10246 \mathrm{~cm}^{-1}$, with a fwhh

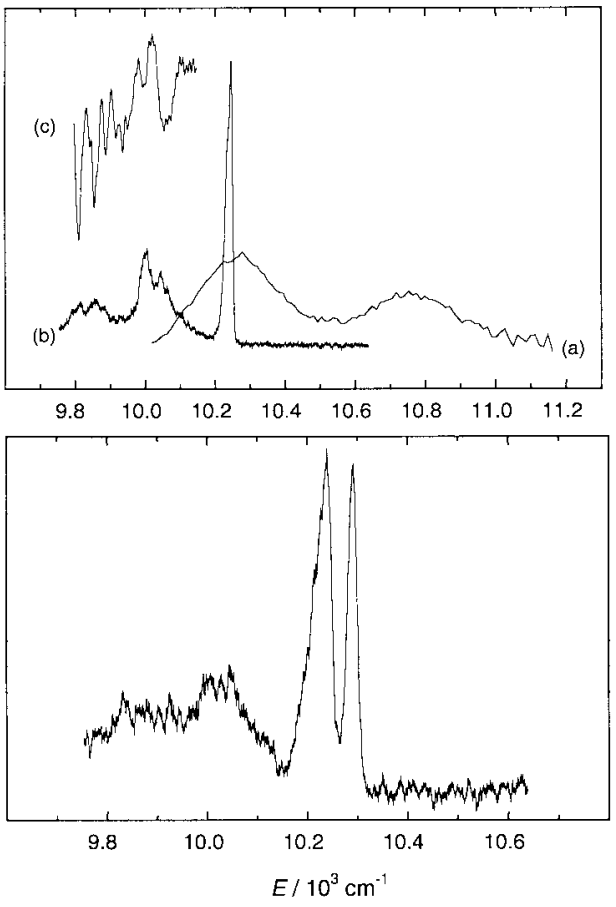

Fig. 5 Top: reflectance (a), emission (solid state, $10 \mathrm{~K}$ ) (b) and IR (c) spectra of $\left[\mathrm{YbL}\left(\mathrm{NO}_{3}\right)\right]\left(\mathrm{NO}_{3}\right)_{2} \cdot \mathrm{H}_{2} \mathrm{O}$. Bottom: emission spectrum (solid state, $10 \mathrm{~K})$ of $\left[\mathrm{Yb}_{2}(\mathrm{~L}-3 \mathrm{H})\left(\mathrm{NO}_{3}\right)_{2}\right]\left(\mathrm{NO}_{3}\right) \cdot 3 \mathrm{H}_{2} \mathrm{O}$.

of $21 \mathrm{~cm}^{-1}$, assigned to the ${ }^{2} \mathrm{~F}_{5 / 2} \rightarrow{ }^{2} \mathrm{~F}_{7 / 2}$ transition and a group of less intense bands between 10150 and $9750 \mathrm{~cm}^{1}$, arising from vibronic transitions (Fig. 5). The intensity of the $\mathrm{Yb}$ emission arises from two factors: the energy difference between the ligand triplet state and $\mathrm{Yb}\left({ }^{2} \mathrm{~F}_{5 / 2}\right), c a .5000 \mathrm{~cm}^{-1}$, is favourable to an efficient energy transfer and the energy gap $\Delta E\left({ }^{2} \mathrm{~F}_{3 / 2}{ }^{2} \mathrm{~F}_{7 / 2}\right)$ is larger than in the case of $\mathrm{Nd}(\mathrm{III})$, which renders non-radiative deactivation processes slower. The emission properties of $\mathbf{5}$, $10^{-3} \mathrm{M}$ in $\mathrm{H}_{2} \mathrm{O}, \mathrm{D}_{2} \mathrm{O}$ and $\mathrm{d}_{6}$-DMSO at $295 \mathrm{~K}$, were also studied. The spectra display a strong single band in all cases, appearing at $10230 \mathrm{~cm}^{-1}$ in $\mathrm{H}_{2} \mathrm{O}$ or $\mathrm{D}_{2} \mathrm{O}$ solution and at $10220 \mathrm{~cm}^{-1}$ in $\mathrm{d}_{6}$-DMSO. The intensity of the $\mathrm{Yb}$ (III) emission in solution is higher in $\mathrm{d}_{6}$-DMSO, in which the ligating group stretching harmonics do not correspond well to the energy of the ${ }^{5} \mathrm{~F}_{5 / 2}$ state, as was previously observed. ${ }^{14}$

\section{Photophysical properties of the bimetallic cryptates}

As for the Gd 1:1 cryptate, the emission spectrum of the Lu(III) bimetallic complex 9 at $10 \mathrm{~K}$ displays two ligand-centred emission band, one at $18250 \mathrm{~cm}^{-1}$ arising from the ${ }^{1} \pi \pi^{*}$ state and the other at $16600 \mathrm{~cm}^{-1}$ originating from the triplet state. The latter has a single-exponential time decay with a lifetime of $24 \mathrm{~ms}$. The quantum yield of the ligand-centred luminescence, as measured for a $10^{-3} \mathrm{M}$ solution in DMSO, is again very low, $Q^{\mathrm{F}}=0.4 \%$. Consistent with a ${ }^{3} \pi \pi^{*}$ state having an energy lower than that of the ${ }^{5} \mathrm{D}_{4}$ level, the $\mathrm{Tb}$ bimetallic cryptate can only be excited through the $\mathrm{Tb}$ (III) levels, in the UV region of the spectrum, and at low temperature. The lifetime of the $\operatorname{Tb}\left({ }^{5} \mathrm{D}_{4}\right)$ level amounts to $0.44 \pm 0.01 \mathrm{~ms}$ at $77 \mathrm{~K}$, a value reflecting important deactivation processes taking place, which prevent observation of any luminescence at room temperature. The Eu cryptate could not be investigated because bimetallic cryptates form only with smaller lanthanide ions $(\mathrm{Ln}=\mathrm{Gd}-\mathrm{Lu}) .{ }^{18}$

At $10 \mathrm{~K}$, the $\mathrm{Yb}$ cryptate $\mathbf{8}$, displays two intense bands at $10240 \mathrm{~cm}^{-1}\left(\mathrm{fwhh}=23 \mathrm{~cm}^{-1}\right)$ and $10290 \mathrm{~cm}^{-1}$ (fwhh $=43$ $\mathrm{cm}^{-1}$ ), and a group of less intense peaks between 10150 and $9760 \mathrm{~cm}^{-1}$, assigned to vibronic transitions. As the ${ }^{2} \mathrm{~F}_{5 / 2} \rightarrow{ }^{2} \mathrm{~F}_{7 / 2}$ transition can only display a unique component, the observation of two emission bands is consistent with the presence of two $\mathrm{Yb}(\mathrm{III})$ sites with different co-ordination environments. The 

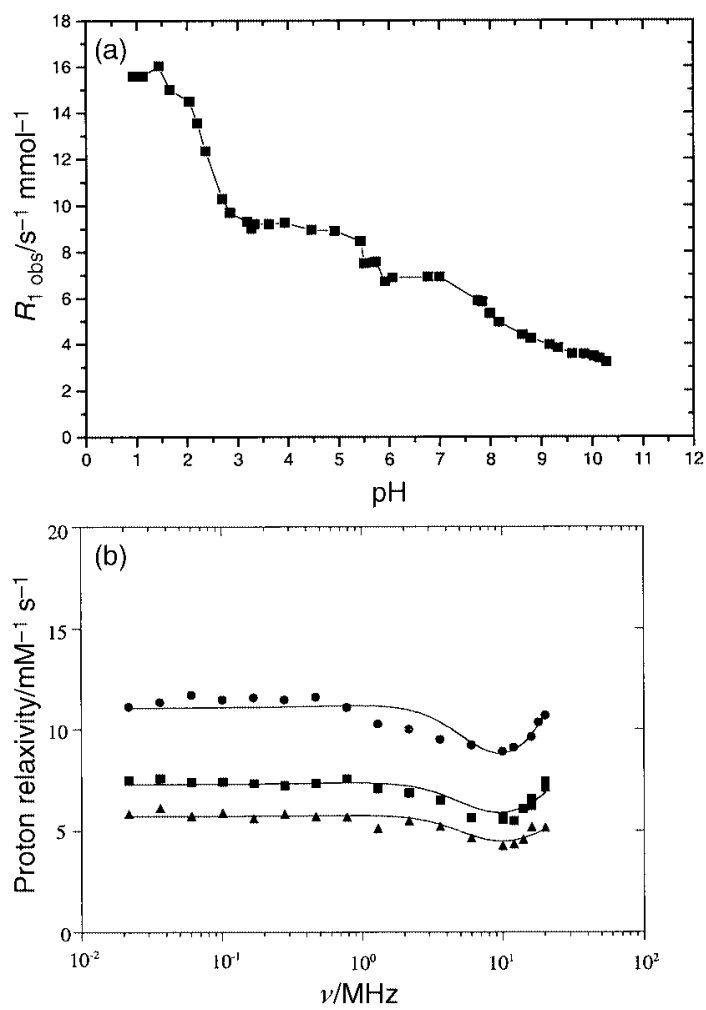

Fig. 6 (a) $\mathrm{pH}$ Dependence of the proton relaxivity observed at $9 \mathrm{MHz}$ and $20{ }^{\circ} \mathrm{C}$ for solutions of $\left[\mathrm{GdL}\left(\mathrm{NO}_{3}\right)\right]\left(\mathrm{NO}_{3}\right)_{2}(3)$. (b) NMRD profiles at pH 6.0 and different temperatures: $-5,-25, \boldsymbol{\Delta} 37^{\circ} \mathrm{C}$. The solid lines through the data have been calculated with the best fit parameters (see text).

emission spectrum of a $10^{-3} \mathrm{M}$ solution in $\mathrm{d}_{6}$-DMSO at $295 \mathrm{~K}$ also displays two bands located at 10220 and $10280 \mathrm{~cm}^{-1}$, which again indicates the presence of two different chemical environments for the $\mathrm{Yb}$ (III) ions. We obtained single crystals of $\mathbf{8}$ for X-ray analysis but they were not of the best quality, so that the structure refinement could not be completed. However, information on the $\mathrm{Yb}(\mathrm{III})$ environments is relatively accurate and these data confirm the presence of two $\mathrm{Yb}(\mathrm{III})$ ions located in the cavity of the anionic Schiff base at an intermetallic distance of 3.44(1) $\AA$. The metal ions present different coordination environments, in agreement with the luminescence data. The $\mathrm{Yb}(1)$ ion is 9 co-ordinate, being bonded to three phenolate oxygen atoms, three azomethine $\mathrm{N}$ atoms, the $\mathrm{N}$ bridgehead atom and to a bidentate nitrate ion. $\mathrm{The} \mathrm{Yb}(2)$ ion is 8 co-ordinate because only two of the 3 azomethine $\mathrm{N}$ atoms are co-ordinated. This may be due to the shortening of the $\mathrm{Ln}-\mathrm{X}$ distances upon increasing atomic number, inducing too large a steric constraint on the ligand which can no longer wrap ideally around the metal ion.

\section{Proton relaxation properties of the monometallic Gd cryptate 3}

Since we have shown the Eu monometallic cryptate being co-ordinated by one water molecule in aqueous solutions, we have investigated the proton relaxivity of 3 at $\mathrm{pH} 6.5$ and various temperatures $\left(5,25\right.$ and $37^{\circ} \mathrm{C}$, Fig. 6). Water proton relaxivity of $\mathrm{Gd}(\mathrm{III})$ complexes has both inner-sphere and outer-sphere contributions, but second-sphere interactions can be neglected in this case. ${ }^{28-31}$ The inner-sphere relaxivity at a fixed radio frequency and temperature depends on a variety of parameters, as shown by the Solomon-Bloembergen-Morgan (SBM) equation:

$$
R_{1} \propto q\left(\mu_{\mathrm{eff}}\right)^{2} \tau_{\mathrm{c}} / r^{6}
$$

where $q$ is the inner-sphere hydration number, taken here as 1 by analogy with the determined value for the Eu cryptate, $\mu_{\text {eff }}$ is the effective magnetic moment of $\mathrm{Gd}(\mathrm{III}), r$ is the internuclear distance between the metal ion and the protons of the coordinated water molecule, and $\tau_{\mathrm{c}}$ is the correlation time for the dipolar interaction. From the large variety of monomeric Gd(III) complexes studied so far, it can be concluded that $R_{1}$ is essentially determined by $q$ and $\tau_{\mathrm{c}}$. The inverse of the latter parameter is determined by the sum of the inverse of the rotational $\left(\tau_{\mathbf{R}}\right)$, electron spin $\left(\tau_{\mathrm{S}}\right)$ and co-ordinated water exchange $\left(\tau_{\mathrm{M}}=1 / k_{\mathrm{ex}}\right)$ correlation times. As pointed out previously, ${ }^{28}$ it is difficult to separate these contributions to the overall proton relaxivity without independent determination of at least some of the most important parameters.

The increase in the relaxivity at high magnetic field $(>10$ $\mathrm{MHz}$ ), observed in the NMRD profiles at all temperatures, is indicative of a relatively long rotational correlation time $\tau_{\mathbf{R}}$. This slow rotation can be explained if we take into account probable dissociation of the bonded nitrato group in dilute aqueous solution and its replacement by a water molecule, leading to a $\left[\mathrm{GdL}\left(\mathrm{H}_{2} \mathrm{O}\right)\right]^{3+}$ species, as demonstrated for the Eu cryptate by lifetime measurements. The large positive charge of the latter then induces second-sphere bonding of water molecules through hydrogen-bonds and thus the whole rotating unit becomes relatively large. The temperature dependence of the NMRD profile usually gives a good indication of which parameter limits proton relaxivity. If the high field value $(>10 \mathrm{MHz})$ increases with increasing temperature, relaxivity is limited by slow water exchange, whereas in the opposite case fast rotation is the limiting factor. For $\mathbf{3}$, the relaxivity increases with decreasing temperature which shows that, despite the relatively long rotational correlation time reflected by the high-field peaks on the profiles, proton relaxivity is still dominated by fast rotation, as is usually observed for small Gd(III) chelates. ${ }^{1,31,32}$

The NMRD profiles have been analysed by using the common Solomon-Bloembergen-Morgan theory for the inner sphere term and the Freed model for the outer sphere relaxation. ${ }^{33}$ The fitted curves are presented in Fig. 6(b) and the resulting parameters are: $k_{\mathrm{ex}}{ }^{298}=(3.9 \pm 0.6) \times 10^{6} \mathrm{~s}^{-1}, \Delta H^{\ddagger}=$ $25.2 \pm 2 \mathrm{~kJ} \mathrm{~mol}^{-1}, \Delta S^{\ddagger}=-34 \pm 2 \mathrm{~J} \mathrm{~mol}^{-1} \mathrm{~K}^{-1}, \tau_{\mathrm{R}}{ }^{298}=310 \pm 30$ ps, $E_{\mathrm{R}}=29.6 \pm 2 \mathrm{~kJ} \mathrm{~mol}^{-1}, \tau_{\mathrm{v}}{ }^{298}=16 \pm 4 \mathrm{ps}, E_{\mathrm{v}}=1 \mathrm{~kJ} \mathrm{~mol}^{-1}$, $\Delta^{2}=1.1 \pm 0.2 \times 10^{20} \mathrm{~s}^{-2}, \quad D_{\mathrm{GdH}}{ }^{298}=(25 \pm 2) \times 10^{-10} \mathrm{~m}^{2} \quad \mathrm{~s}^{-1}$ and $E_{\mathrm{GdH}}=31.7 \pm 2 \mathrm{~kJ} \mathrm{~mol}^{-1}$. The water exchange rate is very similar to that obtained for $\left[\mathrm{Gd}(\text { DOTA })\left(\mathrm{H}_{2} \mathrm{O}\right)\right]^{-}($DOTA $=$ 1,4,7,10-tetraazacyclododecane-1,4,7,10-tetraacetate) or [Gd$\left.(\mathrm{DTPA})\left(\mathrm{H}_{2} \mathrm{O}\right)\right]^{2-} \quad\left(\mathrm{DTPA}=N, N, N^{\prime}, N^{\prime \prime}, N^{\prime \prime}\right.$-diethylenetriaminepentaacetate). ${ }^{33}$ The mechanism, as indicated by the negative activation entropy, is associatively activated. This is in agreement with $q=1$ which leads to an overall co-ordination number of 8 . It is well known that Gd(III) complexes exist with 8 or 9 co-ordination, thus for the eight co-ordinate $[\mathrm{GdL}]^{3+}$ one can expect an associatively activated water exchange process.

The relaxivity is unchanged in a narrow $\mathrm{pH}$ range from 7.3 to 5.9 [Fig. 6(a)] due to the hydration state of the complex $(q=1)$. From pH 5.9 to 5.4 it increases by $c a$. $20 \%$ compared with the value at $\mathrm{pH} 7.0$, and stays almost constant down to $\mathrm{pH} 3.2$, probably reflecting the penetration of an additional water molecule into the first co-ordination sphere of the $\mathrm{Gd}^{3+}$ ion. Protonation of the ligand, possibly at one imine $\mathrm{N}$ atom, leads to partial ligand decomposition, but not $\mathrm{Gd}^{3+}$ dissociation, as shown by the absence of free Gd(III) from colorimetric tests with arsenazo II or xylenol orange indicators. This is supported by the ${ }^{1} \mathrm{H}$ NMR spectra of the Sm monometallic cryptate in $\mathrm{D}_{2} \mathrm{O},{ }^{17}$ which remain unchanged with time at $\mathrm{pH}>5.5$, but displays a new set of signals at $\mathrm{pH}<5.5$. The spectrum of the new species does not correspond to the free ligand but, rather, to a product of partial decomposition. The rate of appearance of this product increases at lower $\mathrm{pH}$ : at $\mathrm{pH} 3.4$ it is $90 \%$ formed after $15 \mathrm{~min}$. The relaxivity of $[\mathrm{GdL}]^{3+}$ increases drastically at $\mathrm{pH}<3.2$, reaching values typical of the free $\mathrm{Gd}(\mathrm{III})$ ion and indicating full dissociation of the complex. In the $\mathrm{pH}$ range $7-10$, the relaxivity decreases due to the competition of $\mathrm{OH}^{-}$ ions for binding to the $\mathrm{Gd}(\mathrm{III})$ ions. ${ }^{34,35}$ 


\section{Conclusions}

The axial Schiff base macrobicyclic receptor $\mathrm{L}$ is a versatile ligand that allows the formation of both monometallic and bimetallic lanthanide cryptates. The X-ray crystal structures of the monometallic and bimetallic dysprosium cryptates $\mathbf{4}$ and 7 confirm the encapsulation of the lanthanide ion into the cavity and show that the co-ordinating atoms are strong enough donors to keep a short Dy-Dy contact, of the order of $3.5 \AA$. A detailed photophysical study of the crystalline Eu(III) monometallic complex $\mathbf{2}$ is consistent with the presence of a single low symmetry $\mathrm{Eu}(\mathrm{III})$ site and with a large nephelauxetic effect induced by the imine $\mathrm{N}$-atoms, as also revealed by ${ }^{1} \mathrm{H}-\mathrm{NMR}$ spectra. The ligand-to-Eu(III) energy transfer is relatively efficient at low temperature, but back transfer is implied in the deactivation process, especially at room temperature, because the ligand triplet state lies at very low energy, which prevents sensitisation of the $\mathrm{Tb}$ (III) ion. On the other hand, the low energy of the ${ }^{3} \pi \pi^{*}$ state in both $\mathrm{L}$ and $(\mathrm{L}-3 \mathrm{H})^{3-}$ cryptands provides an efficient conversion of the visible light absorbed into near infrared light emitted by $\mathrm{Yb}$ (III) ions, which opens interesting perspectives for the design of nanometric lightconverting devices, for instance for diode lasers. Another advantage stemming from these cryptates is the facile replacement of the bonded nitrato ion in aqueous solutions of the monometallic cryptates by a water molecule, inducing a relaxivity in solutions of the Gd complex larger than those reported for the standard contrast agents with DOTA or DTPA. ${ }^{1}$ In conclusion, the investigated cryptates may be of use in several fields of lanthanide co-ordination chemistry, ranging from the design of light-converting devices to luminescent stains and contrast agents, and judicious substitution of the cryptand skeleton should enable improved properties in several of these applications to be obtained.

\section{Experimental}

\section{Syntheses and characterisations}

2,6-Diformyl-4-methylphenol was prepared according to the literature method. ${ }^{36}$ Tris(2-aminoethyl)amine and the lanthanide nitrates were from Aldrich and Alfa Laboratories and used without further purification. Solvents for synthesis were of reagent grade purified by the usual methods. Solvents for luminescence measurements were purchased from Fluka AG (Buchs, Switzerland) and used without further purification.

1:1 complexes. The complexes of formula $\left[\mathrm{LnL}\left(\mathrm{NO}_{3}\right)\right]-$ $\left(\mathrm{NO}_{3}\right)_{2} \cdot x \mathrm{H}_{2} \mathrm{O} \quad(x=1-4)$ were synthesised as previously described. ${ }^{17}$ Crystals of formula $\left[\mathrm{DyL}\left(\mathrm{NO}_{3}\right)\right]\left(\mathrm{NO}_{3}\right)_{2} \cdot 2 \mathrm{CH}_{3}-$ $\mathrm{CN} \cdot 0.5 \mathrm{H}_{2} \mathrm{O}(4)$ suitable for X-ray diffraction were grown from an acetonitrile-toluene 1:1 solution of the isolated solid.

$\left[\mathrm{Tb}_{2}(\mathrm{~L}-3 \mathrm{H})\left(\mathrm{NO}_{3}\right)_{2}\right]\left(\mathrm{NO}_{3}\right) \cdot \mathrm{H}_{2} \mathrm{O} \cdot \mathbf{E t O H}(6)$. A solution of $0.075 \mathrm{~mL}$ of tren $(0.50 \mathrm{mmol}$ in absolute ethanol, $30 \mathrm{~mL})$ was slowly added to a refluxing and stirred solution of $\mathrm{Tb}\left(\mathrm{NO}_{3}\right)_{3} \cdot 6 \mathrm{H}_{2} \mathrm{O}(0.218 \mathrm{~g}, 0.50 \mathrm{mmol})$ and triethylammonium 2,6-diformyl-4-methylphenolate $(0.199 \mathrm{~g}, 0.75 \mathrm{mmol})$ in absolute ethanol $(30 \mathrm{~mL})$. After the addition was completed, the resultant orange solution was stirred and refluxed for $5 \mathrm{~h}$. The orange precipitate formed was filtered off. The filtrate was concentrated under vacuum to $20 \mathrm{~mL}$ and left to evaporate slowly at room temperature to yield a microcrystalline solid that was filtered and dried under vacuum (yield $35 \%$ ). Analysis found: $\mathrm{C}$, 39.7; H, 4.3; N, 12.4. Calc. for $\mathrm{C}_{39} \mathrm{H}_{45} \mathrm{~N}_{11} \mathrm{O}_{12} \mathrm{~Tb}_{2} \cdot \mathrm{H}_{2} \mathrm{O} \cdot \mathrm{EtOH}$ : $\mathrm{C}, 39.7 ; \mathrm{H}, 4.3 ; \mathrm{N}, 12.5 \% . v(\mathrm{HC}=\mathrm{N}) 1639, v\left(\mathrm{NO}_{3}{ }^{-}\right) 1456,1411$, $1281,1025,810 \mathrm{~cm}^{-1}$ (KBr disc). FAB mass spectrum: $\mathrm{m} / \mathrm{z} 1115$ $\left[\mathrm{Tb}(\mathrm{L}-3 \mathrm{H})\left(\mathrm{NO}_{3}\right)_{2}\right]^{+}$.

$\left[\mathrm{Dy}_{2}(\mathrm{~L}-\mathbf{3 H})\left(\mathrm{NO}_{3}\right)_{2}\right]\left(\mathrm{NO}_{3}\right) \cdot \mathbf{H}_{2} \mathrm{O} \cdot \mathbf{E t O H}$ (7). The orange cryptate was prepared in $15 \%$ yield as described for $\mathbf{6}$ by using $\mathrm{Dy}\left(\mathrm{NO}_{3}\right)_{3} \cdot 6 \mathrm{H}_{2} \mathrm{O}(0.218 \mathrm{~g}, 0.50 \mathrm{mmol})$. Analysis found: C, 39.9;
$\mathrm{H}, 4.3 ; \mathrm{N}, 12.3$. Calc. for $\mathrm{C}_{39} \mathrm{H}_{45} \mathrm{~N}_{11} \mathrm{O}_{12} \mathrm{Dy}_{2} \cdot \mathrm{H}_{2} \mathrm{O} \cdot$ EtOH: C, 39.6; $\mathrm{H}, 4.4 ; \mathrm{N}, 12.4 \% . v(\mathrm{HC}=\mathrm{N}) 1639, v\left(\mathrm{NO}_{3}{ }^{-}\right) 1456,1411,1282$, $1027,812 \mathrm{~cm}^{-1}$ (KBr disc). FAB mass spectrum: $\mathrm{m} / \mathrm{z} 1122$ $\left[\mathrm{Dy}(\mathrm{L}-3 \mathrm{H})\left(\mathrm{NO}_{3}\right)_{2}\right]^{+}$. Orange crystals of formula $\left[\mathrm{Dy}_{2}(\mathrm{~L}-\right.$ $\left.3 \mathrm{H})\left(\mathrm{NO}_{3}\right)_{2}\right]\left(\mathrm{NO}_{3}\right) \cdot 3 \mathrm{H}_{2} \mathrm{O} \cdot \mathrm{MeOH}$ suitable for single crystal $\mathrm{X}$-ray diffraction were grown by slow evaporation of the mother liquor at room temperature.

$\left[\mathrm{Yb}_{2}(\mathrm{~L}-\mathbf{3 H})\left(\mathrm{NO}_{3}\right)_{2}\right]\left(\mathrm{NO}_{3}\right) \cdot \mathbf{2} \mathrm{H}_{2} \mathbf{O} \cdot \mathbf{E t O H}(\mathbf{8})$. The orange cryptate was prepared in $15 \%$ yield as described for $\mathbf{6}$ by using $\mathrm{Yb}\left(\mathrm{NO}_{3}\right)_{3} \cdot 5 \mathrm{H}_{2} \mathrm{O}(0.225 \mathrm{~g}, 0.50 \mathrm{mmol})$. Analysis found: $\mathrm{C}, 38.2$; $\mathrm{H}, 4.3 ; \mathrm{N}, 12.0$. Calc. for $\mathrm{C}_{39} \mathrm{H}_{45} \mathrm{~N}_{11} \mathrm{O}_{12} \mathrm{Yb}_{2} \cdot 2 \mathrm{H}_{2} \mathrm{O} \cdot \mathrm{EtOH}$ : C, 38.3 ; H, 4.3; N, 12.0\%. v( $\mathrm{HC}=\mathrm{N}) 1639, v\left(\mathrm{NO}_{3}^{-}\right) 1456,1411$, $1282,1027,812 \mathrm{~cm}^{-1}$ (KBr disc). FAB mass spectrum: $\mathrm{m} / z 1143$ $\left[\mathrm{Yb}(\mathrm{L}-3 \mathrm{H})\left(\mathrm{NO}_{3}\right)_{2}\right]^{+}$.

$\left[\mathrm{Lu}_{2}(\mathrm{~L}-\mathbf{3 H})\left(\mathrm{NO}_{3}\right)_{2}\right]\left(\mathrm{NO}_{3}\right) \cdot \mathbf{2} \mathrm{H}_{2} \mathrm{O} \cdot \mathbf{E t O H}$ (9). The orange cryptate was prepared in $15 \%$ yield as described for 6 by using $\mathrm{Lu}\left(\mathrm{NO}_{3}\right)_{3} \cdot 5 \mathrm{H}_{2} \mathrm{O}(0.226 \mathrm{~g}, 0.50 \mathrm{mmol})$. Analysis found: $\mathrm{C}, 38.1$; $\mathrm{H}$, 4.3; N, 11.9. Calc. for $\mathrm{C}_{39} \mathrm{H}_{45} \mathrm{~N}_{11} \mathrm{O}_{12} \mathrm{Lu}_{2} \cdot 2 \mathrm{H}_{2} \mathrm{O} \cdot \mathrm{EtOH}$ : C, $38.5 ; \mathrm{H}, 4.3 ; \mathrm{N}, 12.1 \% . v(\mathrm{HC}=\mathrm{N}) 1655, v\left(\mathrm{NO}_{3}^{-}\right) 1470,1312$, $1013,822 \mathrm{~cm}^{-1}$ (KBr disc). FAB mass spectrum: $m / z 1147$ $\left[\mathrm{Lu}(\mathrm{L}-3 \mathrm{H})\left(\mathrm{NO}_{3}\right)_{2}\right]^{+}$.

\section{Physicochemical measurements}

Elemental analyses were carried out on a Carlo Erba EA 1108 elemental analyser. The IR spectra were recorded using a Perkin-Elmer 1330 spectrometer and FAB mass spectra using a Fisons Quattro mass spectrometer with a caesium-ion gun and thioglycerol as matrix. Reflectance spectra were recorded from finely ground powders dispersed in $\mathrm{MgO}(5 \%)$ with $\mathrm{MgO}$ as the reference on a Perkin-Elmer Lambda 900 spectrometer equipped with a Labsphere RSA-PE-19 integration sphere. Electronic spectra were recorded from the UV-visible range at $20{ }^{\circ} \mathrm{C}$, either with a Perkin-Elmer Lambda 7 or an Uvikon 941 Plus spectrophotometer using 1.0 and $0.1 \mathrm{~cm}$ quartz cells. Low resolution excitation and emission spectra were recorded with a Perkin-Elmer LS-50B spectrometer equipped for lowtemperature $(77 \mathrm{~K})$ measurements. Quantum yields were calculated on $10^{-3} \mathrm{M}$ solutions in methanol using quinine sulfate in dilute sulfuric acid as the reference (absolute quantum yield: $0.546^{37}$ ). The experimental details for highresolution laser excited luminescence measurements were previously described. ${ }^{19 a, 38}$ Lifetimes are averages of at least 3-5 independent determinations. Longitudinal water proton relaxation rates $\left(1 / T_{1}\right)$ as a function of the solution $\mathrm{pH}$ were measured at $20^{\circ} \mathrm{C}$ using an MRS-4 NMR relaxometer (Jozef Stefan Institute, Ljubljana, Slovenia) operating at $9 \mathrm{MHz}$. The $1 / T_{1}$ nuclear magnetic relaxation dispersion (NMRD) profiles of the solvent protons at 5,25 and $37^{\circ} \mathrm{C}$ and $1 \mathrm{mM}$ concentration were obtained on a Spinmaster FFC Fast Field Cycling NMR relaxometer (Stelar), covering a continuum of magnetic fields from $7 \times 10^{-4}$ to $0.47 \mathrm{~T}$ (corresponding to a proton Larmor frequency range of $0.03-20 \mathrm{MHz}$ ). $T_{1}$ values were measured using the inversion recovery method. ${ }^{1} \mathrm{H}$ High resolution NMR spectra were recorded in $\mathrm{D}_{2} \mathrm{O}$ solutions on a Varian Unity-500 NMR spectrometer operating at $499.824 \mathrm{MHz}$. Deuterated 3-(trimethylsilyl)-1-propanesulfonic acid, sodium salt, was used as the internal chemical shift reference.

\section{X-Ray crystal structure determinations}

Three dimensional X-ray data were collected on a Siemens Smart 1000 CCD diffractometer by the $\Omega$-scan method. Complex scattering factors were taken from the program package SHELXL-97. ${ }^{39}$ For 7, the absolute configuration has been established by refinement of the enantiomorph polarity parameter $[x=-0.011(14)] .^{40}$ The structure of 7 presents a slight disorder on an oxygen of one co-ordinated nitrate and another of the ionic nitrate. These disorders have been resolved and two atomic sites have been observed and refined with isotropic 
Table 5 Crystal data and structure refinement for $\mathbf{4}$ and $\mathbf{7}$

\begin{tabular}{|c|c|c|}
\hline & 4 & 7 \\
\hline Formula & $\mathrm{C}_{43} \mathrm{H}_{55} \mathrm{DyN}_{13} \mathrm{O}_{12.50}$ & $\mathrm{C}_{40} \mathrm{H}_{55} \mathrm{Dy}_{2} \mathrm{~N}_{11} \mathrm{O}_{16}$ \\
\hline$M$ & 1116.50 & 1270.95 \\
\hline Crystal system & Triclinic & Tetragonal \\
\hline Space group & $P \overline{1}$ & $P 4_{1} 2_{1} 2$ \\
\hline$T / \mathrm{K}$ & 293(2) & 193(2) \\
\hline$a / \AA ̊$ & $10.067(4)$ & $17.7170(3)$ \\
\hline$b / \AA$ & $12.5040(19)$ & $17.7170(3)$ \\
\hline$c / \AA ̊$ & $18.897(4)$ & 29.180 \\
\hline$a /^{\circ}$ & $95.471(15)$ & 90 \\
\hline$\beta /^{\circ}$ & $92.50(2)$ & 90 \\
\hline$\gamma / 1^{\circ}$ & $96.038(18)$ & 90 \\
\hline$V / \AA^{3}$ & 2351.3(10) & $9173.0(2)$ \\
\hline$F_{000}$ & 1140 & 5056 \\
\hline$Z$ & 2 & 8 \\
\hline$D_{\text {calc }} / \mathrm{g} \mathrm{cm}^{-3}$ & 1.577 & 1.841 \\
\hline$\mu / \mathrm{mm}^{-1}$ & 1.666 & 3.317 \\
\hline$R_{\text {int }}$ & 0.0834 & 0.0779 \\
\hline No. of measured reflections & 15662 & 63979 \\
\hline No. of observed reflections & 5126 & 9353 \\
\hline$R_{1}$ & 0.0889 & 0.0432 \\
\hline$w R_{2}$ (all data) & 0.1587 & 0.1021 \\
\hline \multicolumn{3}{|c|}{$R_{1}=\Sigma|| F_{\mathrm{o}}\left|-F_{\mathrm{c}}\right||/ \Sigma| F_{\mathrm{o}} \mid \cdot w R_{2}=\left\{\Sigma\left[w\left(\left.|| F_{\mathrm{o}}\right|^{2}-\left|F_{\mathrm{c}}\right|^{2} \mid\right)^{2}\right] / \Sigma\left[w\left(F_{\mathrm{o}}^{4}\right)\right]\right\}^{\frac{1}{2}}$} \\
\hline
\end{tabular}

atomic displacement parameters in each case. The sites occupancy factors were 0.37883 for $\mathrm{O}(9 \mathrm{~A})$ and 0.40192 for $\mathrm{O}(12 \mathrm{~A})$. Crystal data and details on data collection and refinement are summarised in Table 5.

CCDC reference number 186/1766.

See http://www.rsc.org/suppdata/dt/a9/a906675f/ for crystallographic files in .cif format.

\section{Acknowledgements}

C. P., F. A., A. de B. and T. R.-B. thank Xunta de Galicia (PGIDT99PXI20902B) for financial support. C. P. also thanks Xunta de Galicia for a research grant. C. F. G. C. G. acknowledges support from the Portuguese Foundation for Science and Technology (grant Praxis 2/2.2/SAU/1194/95), the E.U. COST D8 action and the BIOMED program (MACE Project). J.-C. G. B. and A. M. thank the Swiss National Science Foundation, the Office for Education and Science (OFES) and Nycomed Inc. for their financial support.

\section{References}

1 P. Caravan, J. J. Ellison, T. J. McMurry and R. B. Lauffer, Chem Rev., 1999, 99, 2293; R. B. Lauffer, in MRI Clinical Magnetic Resonance Imaging, ed. R. R. Edelman, M. B. Zlatkin and J. R. Hesselink, W. B. Saunders Co., Philadelphia, PA, 2nd edn., 1996, vol. 1 , ch. 5 .

2 T. C. Bruice, A. Tsubouchi, R. O. Dempey and L. P. Olson, J. Am. Chem. Soc., 1996, 118, 9867.

3 Bioanalytical Applications of Labelling Technologies, ed. I. Hemmilä, T. Ståhlberg and P. Mottram, Wallac Oy, Turku, Finland, 1994.

4 G. L. DeNardo, G. R. Mirik, L. A. Kroger, R. T. O’Donnel, C. F. Meares and S. J. DeNardo, J. Nucl. Med., 1996, 37, 451.

5 J.-C. G. Bünzli, N. André, M. Elhabiri, G. Muller and C. Piguet, J. Alloys Compd., in press; J.-C. G. Bünzli, in Rare Earths, ed. R. Saez-Puche and P. Caro, Editorial Complutense, Madrid, 1998, p. 223.

6 V. Alexander, Chem Rev., 1995, 95, 273.

7 W. T. Carnall, in Handbook on the Physics and Chemistry of Rare Earths, ed. K. A. Gschneidner, Jr. and L. Eyring, Elsevier, Amsterdam, 1987, vol. 3, p. 171

8 S. V. Shevchuk, E. A. Alexeeva, N. V. Rusakova, Y. V. Korovin V. A. Bacherikov and A. I. Gren, Mendeleev Commun., 1998, 3, 112.

9 G. A. Crosby and M. Kasha, Spectrochim. Acta, 1958, 10, 377; W. G. Perkins and G. A. Crosby, J. Chem. Phys., 1965, 42, 407.

10 M. Gouterman, C. D. Shumaker, T. S. Srivastava and T. Yonetani, Chem. Phys. Lett., 1976, 40, 476; M. I. Gaiduk, V. V. Grigoryants, A. F. Mironov, V. D. Rumyantseva, V. I. Chissov and G. M. Sukhin, J. Photochem. Photobiol. B, 1990, 7, 15.
11 J. Hall, R. Häner, S. Aime, M. Botta, S. Faulkner, D. Parker and A. S. de Sousa, New J. Chem., 1998, 627.

12 A. Beeby, R. S. Dickins, S. Faulkner, D. Parker and J. A. Gareth Williams, Chem. Commun., 1997, 1401.

13 W. D. Horrocks, Jr., J. P. Bolender, W. D. Smith and R. M. Supkowski, J. Am. Chem. Soc., 1997, 119, 5972.

14 Y. Hasegawa, K. Murakoshi, Y. Wada, S. Yanagida, J.-H. Kim, N. Nakashima and T. Yamanaka, Chem. Phys. Lett., 1996, 248, 8; M. P. O. Wolbers, F. C. J. M. van Veggel, F. G. A. Peters, E. S. E. van Beelen, J. W. Hofstraat, F. A. J. Geurts and D. N. Reinhoudt, Chem. Eur. J., 1998, 4, 772; S. Yanagida, Y. Hasegawa, K. Murakoshi, Y. Wada, N. Nakashima and T. Yamanaka, Coord. Chem. Rev., 1998, 171, 461.

15 F. Avecilla, R. Bastida, A. de Blas, D. E. Fenton, A. Macías, A. Rodríguez, T. Rodríguez-Blas, S. García-Granda and R. CorzoSuárez, J. Chem. Soc., Dalton Trans., 1997, 409; F. Avecilla, R. Bastida, A. de Blas, E. Carrera, D. E. Fenton, A. Macías, C. Platas, A. Rodríguez and T. Rodríguez-Blas, Z. Naturforsch., Teil B, 1997, 52, 1273.

16 M. G. B. Drew, O. W. Howarth, C. J. Harding, N. Martin and J. Nelson, J. Chem. Soc., Chem. Commun., 1995, 903.

17 C. Platas, F. Avecilla, A. de Blas, C. F. G. C. Geraldes, T. RodriguezBlas, H. Adams and J. Mahia, Inorg. Chem., 1999, 38, 3190.

18 F. Avecilla, A. de Blas, R. Bastida, D. E. Fenton, J. Mahia, A. Macias, C. Platas, A. Rodriguez and T. Rodriguez-Blas, Chem. Commun., 1999, 125.

19 (a) P. Guerriero, P. A. Vigato, J.-C. Bünzli and E. Moret, J. Chem. Soc., Dalton Trans., 1990, 647; (b) J. Bruno, B. R. Herr and W. DeW. Horrocks, Jr., Inorg. Chem., 1993, 32, 756; (c) I. A. Kahwa, S. Folkes, D. J. Williams, S. V. Ley, C. A. O'Mahoney and G. L. McPherson, J. Chem. Soc., Chem. Commun., 1989, 1531; (d) F. Benetollo, G. Bombieri, K. K. Fonda and L. M. Vallarino, Polyhedron, 1997, 16, 1907; (e) K. K. Fonda, D. L. Smailes, L. M. Vallarino, G. Bombieri, F. Benetollo, A. Polo and L. De Cola, Polyhedron, 1993, 12, 549; $(f)$ J.-C. G. Bünzli, E. Moret, U. Casellato, P. Guerriero and P. A. Vigato, Inorg. Chim. Acta, 1988, 150, 1133; $(g)$ C. Platas, F. Avecilla, A. de Blas, T. Rodríguez-Blas and J.-C. G. Bünzli, J. Chem. Soc., Dalton Trans., 1999, 1763.

20 J. M. Harrowfield, L. Weimin, B. W. Skelton and A. H. White, Aust. J. Chem., 1994, 47, 339; E. K. Brechin, S. G. Harris, S. Parsons and R. E. P. Winpenny, J. Chem. Soc., Dalton Trans., 1997, 1665.

21 M. G. B. Drew, O. W. Howarth, G. G. Morgan and J. Nelson, J. Chem. Soc., Dalton Trans., 1994, 3149.

22 V. A. J. Aruna and V. Alexander, J. Chem. Soc., Dalton Trans., 1996, 1867.

23 J.-C. G. Bünzli, in Lanthanide Probes in Life, Chemical and Earth Sciences. Theory and Practice, ed. J.-C. G. Bünzli and G. R. Choppin, Elsevier Science, Amsterdam, 1989, ch. 7.

24 J.-C. G. Bünzli, B. Klein, D. Wessner and N. W. Alcock, Inorg. Chim. Acta, 1982, 59, 269.

25 S. Petoud, J.-C. G. Bünzli, T. Glanzman, C. Piguet, Q. Xiang and R. P. Thummel, J. Lumin., 1999, 82, 69.

26 S. T. Frey and W. deW. Horrocks, Jr., Inorg. Chim. Acta, 1995, 229, 383.

27 S. Petoud, J.-C. G. Bünzli, K. J. Schenk and C. Piguet, Inorg. Chem., 1997, 36, 1345.

28 R. B. Lauffer, Chem. Rev., 1987, 87, 901

29 M. F. Tweedle, in Lanthanide Probes in Life, Chemical and Earth Sciences. Theory and Practice, ed. J.-C. G. Bünzli and G. R. Choppin, Elsevier Science, Amsterdam, 1989, pp. 127-179.

30 L. Banci, I. Bertini and C. Luchinat, Nuclear and Electron Relaxation, VCH, Weinheim, 1991.

31 J. A. Peters, J. Huskens and D. J. Raber, Prog. Nucl. Magn. Reson. Spectrosc., 1996, 28, 283.

32 S. H. Koenig and R. D. Brown, Magn. Reson. Med., 1984, 1, 478.

33 D. H. Powell, O. M. Ni Dhubhghaill, D. Pubanz, L. Helm, Y. S. Lebedev, W. Schlaepfer and A. E. Merbach, J. Am. Chem. Soc., 1996, 118, 9333.

34 W. D. Kim, G. E. Kiefer, F. Maton, K. McMillan, R. N. Muller and A. D. Sherry, Inorg. Chem., 1995, 34, 2233.

35 S. Aime, M. Botta, S. Geninatti Crich, G. B. Giovenzana, G. Jommi, R. Pagliarin and M. Sisti, Inorg. Chem., 1997, 36, 2992.

36 S. Taniguchi, Bull. Chem. Soc. Jpn., 1984, 57, 2683.

37 S. R. Meech and D. Phillips, J. Photochem., 1983, 23, 193.

38 J.-C. Bünzli and A. Milicic-Tang, Inorg. Chim. Acta, 1996, 252, 221.

39 G. M. Sheldrick, SHELXL97, An Integrated System for Solving and Refining Crystal Structures from Diffraction Data, University of Göttingen, Germany, 1997.

40 G. Bernardinelli and H. D. Flack, Acta Crystallogr., Sect. A, 1985, 41, 500 . 